\title{
ПСИХОЛОГІЧНІ ЗАСОБИ КОНСТРУЮВАННЯ ОСОБИСТІСНОЇ ІДЕНТИЧНОСТІ У ПІДЛІТКОВОМУ ВІЩІ
}

УДК:159. 922

\author{
Чіп P.C. \\ Аспірант кафедри практичної психології Терно- \\ пільського наиіонального педагогічного університе- \\ ту імені Володимира Гнатюка, м. Тернопіль \\ (Украӥна)
}

Анотація. У статті досліджено теоретичні аспекти феномену ідентичність. Проаналізовано різноманітні підходи і наукові погляди вчених, які досліджували проблему особистісної ідентичності. Зосереджено увагу на психологічних особливостях та змістовій характеристиці засобів конструювання особистісної ідентичності у підлітковому віці, яке спрямоване на збереження самоцінності, унікальності і неповторності особистості в умовах сучасних реалій. Розглянуто наукові позиції сучасних дослідників щодо взаємозв'язку ідентичності з іншими психологічними характеристиками. Охарактеризовано вікові закономірності та індивідуально-психологічні особливості розвитку особистісної ідентичності підлітків. Виокремлено перспективи подальших наукових розвідок.

Ключові слова: ідентичність, особистісна ідентичність, ідентифікація, особистість, підлітковий вік, засоби конструювання, мова, гра, діалог, особистісний досвід.

Постановка проблеми. Актуальність проблеми конструювання особистісної ідентичності обумовлена динамічними соціокультурними перетвореннями та активним реформуванням усіх сфер суспільного життя. В резуль- таті трансформації сучасного суспільства пріоритетними стають завдання збереження цілісності особистості, її своєрідності, унікальності і неповторності; становлення і розвитку особистості, здатної долати складні життєві 
ситуації, переживати кризи і конструктивно вирішувати конфлікти. Особливого значення набуває виокремлена проблема у період дорослішання, коли відбувається усвідомлення власної унікальності і неповторності на фоні почуття дорослості і потреби у самоствердженні.

Постановка проблеми на сучасному етапі розвитку суспільства обумовлена не лише недостатнім теоретичним обгрунтуванням та вивченням прикладних аспектів феномену «особистісна ідентичність», а й складністю дослідження, що супроводжується неоднозначністю у концептуальних підходах. Водночас, окрім аналізу теоретичних аспектів визначення сутності виокремленого поняття не менш значущим є дослідження умов і засобів становлення, розвитку, конструювання особистісної ідентичності. 3 огляду на представлені міркування, дослідження проблеми конструювання особистісної ідентичності в умовах сьогодення $€$ досить актуальним і вимагає грунтовного теоретичного аналізу та емпіричного вивчення.

Аналіз останніх досліджень і публікацій. Аналіз наукових праць свідчить про те, що сьогодні надзвичайно важливим $є$ питанням теоретико-методологічних аспектів дослідження особистісної ідентичності, механізмів і засобів іiі становлення і розвитку. Звернення до феномену ідентичності знаходимо у працях сучасних українських науковців у контексті найрізноманітніших психологічних про- блем: самовизначення особистості (В.Л. Зливков та ін.), особистісного зростання (I.С. Булах), саморозвитку (С.Б. Кузікова), самосвідомості (М.Й. Боришевський та ін.), самореалізації (Г.О. Балл та ін.), генези існування особистості С.Д. Максименко), духовності особистості (М.В. Савчин), у контексті ціннісносмислової сфери (З.С. Карпенко, Г.К. Радчук), гендерного виміру особистості (Т.В. Говорун, О.М. Кікінежді), психологічної герменевтики (Н.В. Чепелєва та ін.), у системі сімейних взаємин (Т.М. Яблонська).

Водночас, незважаючи на інтенсивність наукового інтересу до означеної проблеми та значну кількість досліджень у контексті найрізноманітніших психологічних утворень, недостатньо розробленими і вивченими залишаються питання дослідження умов розвитку та засобів конструювання особистісної ідентичності у підлітковому віці, коли активно формується самосвідомість, власна система самооцінювання і самоставлення, здатність проникати у свій внутрішній світ, переживати життєві кризи, опановувати себе у складних критичних ситуаціях і самостійно приймати рішення. Така тенденція вимагає оптимізації умов та засобів конструювання особистісної ідентичності в умовах реформування сучасного суспільства.

Метою статті $є$ здійснення теоретичного огляду та аналізу психологічних досліджень змістової характеристики, умов та засобів конструювання особистісної ідентичності 
у контексті становлення і розвитку особистості підлітка в умовах комунікативного простоpy.

Виклад основного матеріалу і результатів дослідження. Незважаючи на те, що феномен ідентичності уже впродовж кількох десятиліть є об'єктом наукових досліджень, аналіз психолого-педагогічної літератури показав, що у науковців немає єдиного підходу до трактування феномену «ідентичність», в наукових доробках спостерігається неоднозначність щодо визначення поняття «особистісна ідентичність» та висвітлення питання засобів розвитку виокремленого особистісного утворення. Через те, що феномен ідентичності не став предметом глибоких і тривалих досліджень, у психології існують різні погляди щодо змістової та структурної характеристики зазначеного поняття, його різновидів та динаміки розвитку.

Розглядаючи поняття «ідентичність»у соціально-психологічному вимірі, неможливо збагнути його у відриві від особистості і того соціального простору, в якому вона живе. Тому лише в особистісному контексті, зокрема, через активність особистості, іiі суб'єктну позицію, відповідальність і прояви креативності, ідентичність набуває сутності і значущості як у теоретичному, так і в прикладному аспектах. Відтак, вивчаючи проблематику ідентичності у контексті становлення і розвитку особистості, варто зосередити особливу увагу на важливості умов і засобів розвитку саме осо- бистісної ідентичності.

У широкому розумінні ідентичність можна розглядати як складну динамічну систему уявлень особистості про саму себе та пов'язаних із ними переживань, що складається в результаті синтезу визначень індивіда значущими іншими та його самовизначень і апробується в акті вибору. Т.М. Яблонська визначає ідентичність як психологічне ядро особистості, оскільки вона включає в себе визначальні для особистості складові - аспекти iii самосвідомості, ціннісно-смислову та регулятивну сферу [ 8].

Виходячи 3 традиційного розуміння ідентичності як складного феномену, складної психічної реальності, яка включає різні рівні свідомості, індивідуальні і колективні, онтогенетичні і соціогенетичні основи, Л.Б.Шнейдер характеризує у загальному розумінні поняття ідентичність як результат активного рефлексивного процесу, який відображає справжні уявлення суб'єкта про себе, про власний, а не нав’язаний шлях розвитку, який супроводжується відчуттям особистісної визначеності, тотожності і цілісності, що дає можливість суб'єкту сприймати своє життя як досвід тривалості і безперервності свідомості, єдності життєвих цілей і повсякденних вчинків, дій і їх значень, які дозволяють діяти послідовно [7].

Особистісна ідентичність висвітлена авторкою у контексті соціального простору i характеризується відчуттям і усвідомленням 
унікальності «Я» в його екзистенції і неповторності особистісних якостей, при наявності своєї приналежності соціальній реальності [7].

Важливими складовими ідентичності, на думку Л.Б. Шнейдер, є спілкування, досвід, мова. Спілкування і досвід породжують ідентичність, через мовлення вона виражається. Аналіз психологічного смислу виникнення ідентичності дає можливість трактування ідентичності як суб'єктивно-психологічної і об'єктивно-психологічної реальності нашого «Я», як продукт реальності і ментальності. Тому опис ідентичності через досвід, спілкування, мову є найбільш адекватним, адже саме в єдності цих компонентів народжується унікальна, самобутня психічна сутність людини, названа ідентичністю [7].

Виходячи 3 характерного для психологічної герменевтики тлумачення особистості як оповідача історії, Н.В. Чепелєва вважає, що у центрі їі уваги повинна бути проблема «Я». Причому, на відміну від традиційного підходу, який розглядає «Я» як сутність, що може бути описана, психологічна герменевтика акцентує увагу на методах конструювання «Я». Водночас підкреслюється центральна роль мови у формуванні і структуруванні «Я» та ідентичності особистості, як засіб конструювання реальності, особливо реальності особистого досвіду. Варто зазначити, що мова конструює наш внутрішній світ та наші переконання, а особистий досвід отримує значення лише через специфічні лінгвістичні, історичні та соці- альні структури [6].

Особисту ідентичність Н.В. Чепелєва розуміє як сталість рис і характеристик людини, іiі досить стабільне уявлення про себе як про особу, тотожну самій собі, а особистісну ідентичність тлумачить з урахування соціокультурного контексту та залучення особистості в цей контекст. Особистісна ідентичність формується на основі особистої ідентичності, коли людина вибудовує власну історію на основі базових наративів культури, трансформуючи їх відповідно до власних особистих якостей, подій свого життя, тобто на основі власної унікальної особистої історії. Важливу роль у формуванні особистісної ідентичності авторка надає діалогу, зазначаючи, що у процесі осмислення особистого досвіду, а отже, й формування особистісної ідентичності величезну роль відіграє діалог - як зовнішній, так і внутрішній, можна навіть говорити про принципову діалогічність цього процесу. Тільки діалог допомагає особистості рухатися у просторі свого особистого досвіду, формуючи нові концептуальні схеми та наративні структури, а відтак і розвиваючись [5; 6].

Надзвичайно цінними для нашого наукового дослідження мають напрацювання Н.В. Чепелєвої, у яких виокремлено функції наративного конструювання особистісної ідентичності, що сприяють формуванню здатності до саморозуміння, розуміння свого місця у світі, а отже й ефективнішій взаємодії із соціумом і культурою. До основних функцій нара- 
тивного конструювання особистісної ідентичності належать:

$\Rightarrow$ смислоутворювальна, яка не лише дозволяє усвідомити, узгодити та впорядкувати основні смисли буття людини, а й надає їй відчуття авторства власного життя, уявлення (іноді може й ілюзорного), що воно підпорядковане якійсь логіці, порядку, i, взагалі, має сенс не лише в контексті власного буття, а й буття історичного, культурного, соціального;

$\Rightarrow$ конституювальна, тобто така, що дозволяє людині усвідомити себе, свій досвід, вибудувати власну Я-концепцію, базуючись на культурних, особистих та сімейних історіях, і діяти відповідно до цих уявлень;

$\Rightarrow$ розвивальна, яка базується, з одного боку, на уявленнях про себе, на результаті усвідомлення та осмислення власного досвіду, з іншого, - завдяки засвоєнню та привласненню базових наративів культури, дозволяє конструювати себе, створювати життєві плани та програми, бачити життєві перспективи й діяти відповідно до них;

$\Rightarrow$ наратив виступає у вигляді інтерпретаційної рамки, яка накладається людиною на осмислювану реальність, у тому числі й на реальність особистого досвіду, тим самим надаючи йому можливість виконувати інтерпретуючу функцію;

$\Rightarrow \quad$ захисна функція завдяки повторюваності оповіді про складні ситуації, переживання, дозволяє людині немовби відсторонитися від травмуючого досвіду, перевести його у вигляд зовнішньої історії, допомагаючи певною мірою пережити життєві ускладнення, травми, кризові ситуації тощо [6, с. 36].

O.M. Кікінежді, розглядаючи питання конструювання ідентичності у гендерному вимірі особистості, зазначає, що результати здійсненого аналізу дозволяють виокремити наступні принципи конструювання гендерної ідентичності: взаємозв'язок та взаємозумовленість соціальних та психологічних процесів, суспільного та індивідуального рівня; диференціація за ознакою статі; асиметричність; полярність-протиставлення; ієрархічність; андроцентризм. При цьому констатується зв'язок гендерних відмінностей з гендерною нерівністю. У контексті гуманістичної парадигми окреслено проблемне поле гендерного підходу, що включає: соціокультурну природу конструювання рівності-нерівності статей та іiі прояви; біполярний конструкт гендеру (поляризація маскулінності-фемінності як жорстка дефініція статевих ролей в патріархальній культурі); андроцентризм як традиція підпорядкованості жіночої статі та домінування чоловічої; егалітарний (партнерський) конструкт гендеру; сексизм як упереджене та стереотипізоване ставлення; відкрита та прихована дискримінація, гендерна стереотипізація тощо. Особистість, додає авторка, прагне 
утвердити свою гендерну ідентичність в просторі свого буття, у всіх його сферах, що дозволяє їй пережити відчуття самості і неповторності [2].

Презентуючи життєвий світ як концептуальну модель дійсності, Т.М. Титаренко, зазначає, що особистість є цілісністю, що, маючи певну глибину, свідомо і цілеспрямовано самовизначається, передусім, створюючи світ, у якому вона живе, світ власного буття. Велику роль у самостійній інтерпретації навколишньої дійсності, перетворенні ії на світ особистості відіграє мова як головний спосіб тлумачення буття. Реальність життєвого світу описується за допомогою мови сприймання та мислення, переживання та уявлення, що становить той коефіцієнт суб'єктивності, який не можна винести за дужки. Під час спілкування 3 іншою людиною повсякденна особистість переосмислює, переробляє свою власну історію завдяки діалогові, що відбувається [4, с. 34].

На думку Т.М. Титаренко, сучасні дослідники відходять від есенціалістських підходів, від пошуку якоїсь стійкої гомогенної сутності людини. Ідентичність стає сьогодні сутністю, сконструйованою під впливом історико -культурних чинників і зміни в ній відбуваються внаслідок дії різноманітних дискурсивних практик [4, с. 182].

На особливу увагу у контексті дослідження засобів конструювання особистісної ідентичності заслуговує позиція Т.М. Титаре- нко, яка зазначає, що постмодерн є новим дискурсивним простором, у якому гра виступає i як практика конструювання соціальності, i як практика персонального життєконструювання [3, с. 101]. Особистість, яка практикує, з одного боку перебуває у пошуку власної ідентичності, з іншого - сподівається віднайти зручну життєву територію, ще з іншого - активно спілкується у прагненні зустріти справжніх однодумців. Ідентифікування, що ніколи не зупиняється і не добігає кінця, органічно поєднується з автономізацією, котра забезпечує створення і зміни особистісних меж, усвідомлення їхнього сенсу життя для життєконструювання. Практикування, ідентифікування та автономізація як модуси існування сучасної особистості неможливі без постійного діалогування 3 оточенням, соціумом, культурним і природним простором, із власним минулим і майбутнім [3, с. 11].

Завдяки процесам ідентифікування, автономізації, діалогування i практикування відбуваються і конфігурування реальностей, i конституювання себе, і побудова комунікативного простору, які розгортаються чи то одночасно, чи послідовно, чи за якимось іншими ритмами. Специфіка життєконструювання може змінюватися залежно від домінування кожного з процесів, Наприклад, життєконструювання через побудову комунікативного простору потребує активнішого діалогування, а життєконструювання через конфігурування реальностей на певній історичній дистанції 
спирається насамперед на практикування [3, с. 44].

Беручи за основу визначені Т.М. Титаренко складові процесу особистісного конструювання: ідентифікування, автономізацію, діалогування і практикування, що водночас виступають атрибутивними характеристиками особистості, ми вважаємо за можливе трактування виокремлених компонентів як засобів конструювання особистісної ідентичності.

Результати дослідницької діяльності науковців у контексті розгляду проблеми конструювання особистісної ідентичності свідчать про значущість такого феномену як «іграїзація» та вказують на його важливість у процесі життєдіяльності. Зокрема О.М. Кочубейник зазначає, що у модерновому дискурсі гра як соціально-психологічна практика виступає формою конструювання соціальності та життєконструювання особистості за допомогою таких інструментів, як баланс свободи/ несвободи, рівність можливостей і втеча від реальності [3, с. 110]. Фрагметарність, умовність повсякденного життя змушують людину засумніватися в самій соціальній реальності. У віртуалізованій реальності пошуки основи можуть привести лише до конструювання простору, котрий за визначенням є віртуальним. Тому в соціальній віртуальній реальності Інтернету людина нарешті набуває впевненості: вона знає, що це гра, і грає за правилами цієї гри, розширюючи межі власної свободи і творчо переборюючи кризу ідентичності за допо- могою ігор з ідентичністю. Відтак комп'ютеоризація і розвиток мультимедійних засобів віртуальної реальності «викривають» віртуалізованість повсякденного життя. Водночас розвиток технологій і поширення Інтернету провокують подальші масштабні соціальні зміни, продовжуючи тенденцію віртуалізації та експансії гри у світ повсякденного життя. Неназвана, невпізнана, невидима у натовпі людина може повною мірою реалізувати свою віртуальну свободу. Вона сприймає світ як ігрове середовище, вона грає - своїми ролями, своїми ідентичностями. I, зрештою, грає саму себе [3, c. 123].

Інтерпретація гри як універсального i феноменального способу життєдіяльності особистості, який формує іiі ідентичність через невимушену участь в ігрових діях знаходить своє відображення у наукових пошуках російських дослідників. Зокрема, Л.А. Бєляєва та О.М. Новикова трактують гру як спосіб конструювання особистісної ідентичності завдяки дієвому розгортанню власного «Я», коли розуміння себе та іншого відбувається через власне діяння, проживання буття у певній соціокультурній ситуації. Окрім цього, автори характеризують гру як модель взаєморозуміння, так як ігор наодинці не буває. Водночас гра у своїй глибинній основі розгортається як рух назустріч, який вимагає відповіді, що, у свою чергу, відповідає структурі діалогу. Особливого значення грі як способу конструювання особистісної ідентичності надає їі творчий характер, 
що передбачає реалізацію власного задуму або задуму автора, дає можливість активізувати творче мислення, виробити навички самостійного прийняття рішень [1]. Отже, ігрова діяльність у даному контексті розглядається як активна форма особистісного діяння, яка сприяє пошуку себе через самопізнання, саморозуміння і самовизначення, конструюючи, таким чином, особистісну ідентичність

Висновки. Підсумовуючи результати проведеного аналізу проблеми конструювання особистісної ідентичності у підлітковому віці, варто зазначити, що у контексті нашого дослідження важливим аспектом $є$ розгляд ідентичності як складного феномену та динамічного утворення, яке проявляється у формуванні суб'єктної позиції індивіда щодо узагальнених уявлень про себе, як про члена суспільства, про власну цілісність та безперервність.

Теоретичний огляд психологічної літератури та аналіз наукових поглядів багатьох вчених дають можливість зробити висновок про те, що поняття особистісної ідентичності можна розглядати як глибинну і багатогранну категорію, яка конструюється засобами мови, спілкування, діалогу, наративу, особистісного досвіду, гри у відповідності до контексту, який науковці вкладають у суть досліджуваної проблеми. Конструювання особистісної ідентичності можна розглядати як процес самоусвідомлення свого внутрішнього життя та його взаємозв'язку зі світом, зумовлений соціаль- ними впливами на особистість через комп ютерні ігри, соціальні мережі, Інтернет, який перестав бути засобом масової інформації, перетворившись на віртуальний простір пошуку власної ідентичності.

Таким чином, конструювання особистісної ідентичності, яке спрямоване на збереження самоцінності, унікальності, неповторності особистості розглядається як динамічний процес, зумовлений соціальними впливами на особистість, що супроводжується пізнанням самої себе, ставленням до себе і до оточення. Відтак, людина обирає саме той шлях пошуку і конструювання особистісної ідентичності, який найбільше відповідає як вимогам ситуації, так і іiі індивідуальним особливостям, досвіду, емоційному стану, суб'єктному потенціалу. Отож, вибір особистістю певної стратегії подолання критичної ситуації, прийняття рішення визначається як суб' єктивним значенням життєвої ситуації для особистості, іiі цілями, цінностям, переконаннями, так і ії здатністю до оволодіння навичками саморегуляції, можливістю використання власного потенціалу і психологічного ресурcy.

Очевидно, що на даному етапі нашого дослідження вивчення проблеми конструювання особистісної ідентичності у підлітковому віці не можна вважати достатньо вичерпаним. Спроба теоретичного аналізу й отримана інформація спонукає до подальших наукових пошуків. 
Перспективи подальших досліджень. Перспективи подальших розвідок у руслі виокремленої проблематики пов язані з плануванням та проведенням емпіричного дослідження особистісної ідентичності, виявленням особливостей безпосереднього впливу різних соціально-психологічних чинників на процес і1і становлення у період дорослішання.

\section{Перелік використаних джерел:}

1. Беляева Л.А. Игра как способ конст руирования личностной идентичности / Образование и наука. - 2012. № 5(94). - С. 53-55.

2. Кікінежді О.М. Гендерна ідент ичніст ь в онт огенезі особистості: [монографія]. - Тернопіль: Навчальна книга-Богдан, 2011. -400 c.

3. Титаренко T.M. Психологічні практ ики конст руювання життя в умовах постмодерної соціальності: [монографія] / Т.М. Титаренко, О.М. Кочубейник, К.О. Черемних; Національна академія педагогічних наук України, Інститут соціальної та політичної психології. - К.: Міленіум, 2014. - 206c.

4. Титаренко T.M. Жит т євій світ особист ост і : у межах і за межами буденності. - К. : Либідь, 2003. $376 \mathrm{c}$.

5. Чепелєва Н.В. Дослідж ення особист ост і у психологічній герменевтиці / Особистість у розвитку: психологічна теорія і практика: [монографія] / за ред. С.Д. Максименка, В.Л. Зливкова, С.Б. Кузікової. Книга 1. - Суми : Вид-во СумДПУ імені А.С.Макаренка, 2015. - С. $35-56$.

6. Розуміння т а інт ерпрет ація ж ит т євого досвіду як чинник розвитку особистості: монографія / за ред. Н.В. Чепелєвої. - Кіровоград: Імекс - ЛТД, 2013. - 276с.

7. Шнейдер Л.Б. Личност ная, гендерная и профессиональная идентичность: теория и методы диагностики. -
М.: Московский психолого-социальный институт, 2007. - 128c.

8. Яблонська T.M. Розвит ок ідент ичност і дит ини в системі сімейних взаємин: [монографія] . - Суми: Вид.во СумдПУ імені А.С. Макаренка, 2013. - 444c.

\section{References (Transliteration):}

1. Belyaeva L.A. Igra kak sposob konstruirovaniya lichnostnoy identichnosti / Obrazovanie i nauka. - 2012. - \# 5(94). - S. 53-55.

2. KIkInezhdI O.M. Genderna IdentichnIst v ontogenezI osobistostI:b[monografIya]. - TernopIl: Navchalna kniga Bogdan, 2011. - 400s.

3. Titarenko T.M. PsihologIchnI praktiki konstruyuvannya zhittya $\mathrm{v}$ umovah postmodernoYi sotsIalnostI: [monograflya] / T.M. Titarenko, O.M. Kochubeynik, K.O. Cheremnih; NatsIonalna akademIya pedagogIchnih nauk UkraYini, Institut sotsIalnoYi ta polItichnoYi psihologIYi. - K.: MIlenIum, 2014. - 206s.

4. Titarenko T.M. ZhittEvIy svIt osobistostI : u mezhah I za mezhami budennostI / T . M. Titarenko. - K. : LibId, 2003. $-376 \mathrm{~s}$.

5. ChepelEva N.V. DoslIdzhennya osobistostI u psihologIchnIy germenevtitsI /OsobistIst u rozvitku: psihologIchna teorIya I praktika: [monografIya] / za red. S.D. Maksimenka, V.L. Zlivkova, S.B. KuzIkovoYi. Kniga 1. - Sumi : Vid-vo SumDPU ImenI A.S.Makarenka, 2015. - S. 35-56.

6. RozumInnya ta InterpretatsIya zhittEvogo dosvIdu yak chinnik rozvitku osobistostI: monografIya / za red. N.V. ChepelEvoYi. - KIrovograd: Imeks - LTD, 2013. - 276s.

7. Shneyder L.B. Lichnostnaya, gendernaya i professionalnaya identichnost: teoriya i metodyi diagnostiki. - M.: Moskovskiy psihologo-sotsialnyiy institut, 2007. - 128s.

8. Yablonska T.M. Rozvitok IdentichnostI ditini v sistemI sImeynihvzaEmin: [monograflya]. - Sumi: Vid.-vo SumDPU ImenI A.S. Makarenka, 2013. - 444s. 


\section{Chip Ruslana}

Postgraduate student of Prqctical Psychology Department, Ternopil Volodymyr Hnatiuk National Pedagogical University, Ternopil (Ukraine)

\section{PSYCHOLOGICAL METHODS OF CONS- TRUCTION OF PERSONAL IDENITY DU- RING THE PERIOD OF ADOLESCENCE}

\section{ABSTRACT}

In the article the theoretical aspects of the phenomenon of identity. Analyzed various approaches and scientific views of scholars who have studied the problem of personal identity. The emphasis is on psychological and semantic features characteristic means constructing personal identity in adolescence, which aims to preserve the intrinsic value, uniqueness and the uniqueness of the individual in contemporary realities. The concept of personal identity is considered as deep and multifaceted category that is constructed by means of language, communication, dialogue, narrative, personal experience of the game according to the context that the scientists put the essence of studied problems. Construction of personal identity can be seen as a process of self-awareness of his inner life and his relationship with the world, due to social influences on personality through computer games, social networks, the Internet, which is not the media, becoming a virtual space search of its own identity.

Thus, the construction of personal identity, which aims to preserve the intrinsic value, uniqueness, the uniqueness of the individual is seen as a dynamic process, conditioned by social in- fluences on personality, accompanied by the knowledge of himself, attitude to himself and to the environment.

Keywords: identity, personal identity, identification, identity, adolescence, facilities design, language, play, dialogue, personal experience.

\section{Чип Руслана Степановна}

Аспирант кафедры практической психологии Тернопольского национального педагогического университета имени Владимира Гнатюка., г. Тернополь (Украина)

\section{ПСИХОЛОГИЧЕСКИЕ СРЕДСТВА КОНСТРУИРОВАНИЯ ЛИЧНОСТНОЙ ИДЕНТИЧНОСТИ В ПОДРОСТКОВОМ BO3PACTE}

Аннотация. В статье исследованы теоретические аспекты феномена идентичность. Проанализированы различные подходы и научные взгляды ученых, которые исследовали проблему личностной идентичности. Сосредоточено внимание на психологических особенностях и содержательной характеристике средств конструирования личностной идентичности в подростковом возрасте, которое направлено на сохранение самоценности, уникальности и неповторимости личности в условиях современных реалий. Рассмотрены научные взгляды современных исследователей относительно взаимосвязи идентичности с другими личностными характеристиками. Дана характеристика возрастным закономерностям и индивидуально-психологическим особенностям развития личностной идентичности 
подростков. Выделены перспективы дальнейших научных исследований.

Ключевые слова: идентичность, личностная идентичность, идентификация, личность, подростковый возраст, средства конструирования, язык, игра, диалог, личностной опыт. 